\title{
Organisational Information Security Management Maturity Model
}

\author{
Mazlina Zammani ${ }^{1}$ \\ National Cyber Security Agency \\ National Security Council \\ Jalan Impact, 63000, Cyberjaya, Malaysia
}

\author{
Rozilawati Razali ${ }^{2}$, Dalbir Singh ${ }^{3}$ \\ Faculty of Information Science and Technology \\ Universiti Kebangsaan Malaysia \\ 43600, Bangi, Selangor, Malaysia
}

\begin{abstract}
Information Security Management (ISM) is a systematic initiative in managing the organisation's information security. ISM can also be defined as a strategic approach to addressing information security (IS) risks, breaches, and incidents that could threaten the confidentiality, integrity, and availability of information. Although organisations have complied with ISM requirements, security incidents are still afflicting numerous organisations. This issue shows that the current implementation of ISM is still ineffective. The ineffective ISM implementation illustrates the low maturity level. To achieve a higher level of maturity, organisations should always evaluate their ISM practices. Several maturity models have been developed by international organisations, consultants, and researchers to assist organisations in assessing their ISM practices. However, the current models do not evaluate ISM practices holistically. The measurement dimensions in current models are more focused on assessing certain factors only. This caused the maturity assessment to be not executed comprehensively. Therefore, this study aims to address this shortcoming by proposing a comprehensive maturity assessment model that takes into account ISM success factors to evaluate the effectiveness of the implementation. This study adopted a mixedmethod approach, which comprises qualitative and quantitative studies to strengthen the research finding. The qualitative study analyses the existing literature and conducts interviews with nine industry practitioners and six experts while the quantitative study involves a questionnaire survey. The data obtained from the qualitative study were analysed using content analysis while the quantitative data employed statistics analysis. The study identified fourteen success factors and fifty-seven maturity dimensions, which each contains five maturity levels. The proposed model was evaluated through experts' reviews to ensure its accuracy and suitability. The evaluation shows that the model can identify the ISM maturity level systematically and comprehensively. This model will ultimately help the organisations to improve the weaknesses in the implementations thus diminishing security incidents.
\end{abstract}

Keywords-Information security; information security management; maturity models; information security management maturity model

\section{INTRODUCTION}

Now-a-days, organisations' reliance on Information and Communication Technology (ICT) has increased severely due to the rapid development of technology [1],[2],[3],[4],[5]. ICT plays an imperative role in organisations daily operations to ensure the smoothness of the services [6],[7]. In line with the increasing use of ICT in daily operations, organisational information is extremely exposed to security threats and risks [8], [9], [10].

Various efforts have been done to ensure the information is protected. One of the efforts is establishing Information Security Management (ISM). ISM is a strategic approach to addressing information security risks and incidents that could threaten the confidentiality, integrity, and availability of information [10],[11],[12],[13]. However, security incidents endure occurring in organisations [14],[15]. For example, in October 2020, hackers targeted government agencies and telecommunications operators in Iraq, Kuwait, Turkey, and the UAE as part of a cyber espionage campaign [16]. In the latest statistical report released by the National Cyber Coordination and Command Centre, National Cyber Security Agency (NACSA) stated that a total of 4,194 security incidents against public and private organisations were reported in 2020 [17]. This issue shows that the current implementation of ISM is still ineffective [14]. The ineffective ISM implementation illustrates the low maturity level.

Although organisations have complied with ISM requirements set by the industry standards, there is a lack of objective mechanisms to gauge the maturity of the implementation [18]. Even though there are attempts on ISM maturity models [19],[20],[21],[22], they mainly appear as abstract concepts. The current maturity models are typically process-oriented, focusing on measuring security activities and technology aspects without giving much attention to the people aspect, which also contributes to the effectiveness of the ISM implementation [23]. This caused the maturity assessment not executed comprehensively. Thus, the maturity of ISM implementation remains low.

A comprehensive maturity model should consider all aspects in ISM and should not limit to certain aspects only. This study aims to fulfil these needs by proposing a holistic maturity model that considers ISM success factors from four major aspects; People, Process, Organisational Document, and Technology to measure the implementation's effectiveness.

This paper is organised as follows. Section II discussed a review of ISM success factors and the current maturity models. Section III provides the methodology used in this study. Section IV presents the findings and lastly, Section IV summarises the findings. 


\section{BACKGROUND}

\section{A. ISM Success Factors}

ISM provides a strategic direction for implementing security processes and activities to assure security objectives are met, consistent risk management, and effective use of information resources [11],[24]. ISM is likewise a multidisciplinary discipline that should be given due attention to ensuring an appropriate and secure environment in protecting organisational information [25]. Previous studies have indicated that the success of ISM implementation depends on technical and non-technical factors. Those factors are organised into four aspects: People, Organisational Document, Process, and Technology as listed in Table I.

The people aspect consists of individuals or parties directly involved in the ISM. The organisational document refers to strategic and operational documents that need to be developed and adhered to during ISM implementation. Meanwhile, the process aspects consist of ISM key activities and finally, the technology aspect comprises the use of ICT Infrastructure to support the ISM operations. A comprehensive explanation of the factors and their elements can be found in [26].

\section{B. ISM Maturity}

ISM maturity guarantees the successful management of information security [27]. A maturity model is a staged structure where particular security aspects are measured, with the postulation that organisations develop and enhance their ISM implementation from the lowest level to the highest level [27],[28]. Thus far, industries and researchers have developed a few maturity models to assist the organisation in measuring the level of ISM implementation [12],[29].

Control Objectives for Information and Related Technology version 4.1 (COBIT 4.1) is widely used for IT governance [21]. It was developed by IT Governance Institute (ITGI) in the year 2007. This model helps measure an organisation's Information Technology (IT) processes, define a designated maturity level, and improve the process to achieve the preferred maturity level [30]. COBIT 4.1 has six maturity levels, which are from maturity level 0 to maturity level 5.

Another maturity model is Cybersecurity Capability Maturity Model (CMM), developed by Global Cyber Security Capacity Centre in 2014. This model was later revised and improved in 2016 and with a new name Cybersecurity Capability Maturity Model for Nations (CMM). The model allows the organisation to self-assess its current cybersecurity capacity [31]. Conversely, the Open Information Security Management Maturity Model (O-ISM3) by The Open Group assesses maturity based on management processes in four components; general, strategic, tactical, and operational [32]. O-ISM3 has five maturity levels, which look for evidence of the processes in those four components.

Many researchers have adopted the above models in their research work. For example, a study presents a cyclical maturity evaluation model [56] where the maturity level is adopted from COBIT 4.1. The model is based on ISO/IEC 27002 security controls where each implementation of the controls will be assessed. The model outlines eight steps to be followed throughout the assessment. A different researcher proposes a model for measuring ISM performance [46]. The proposed model evaluates the performance based on critical factors, namely, human, processes, risk assessment, and technology. The model contains three maturity levels; basic, intermediate, and advance.

TABLE I. ISM SUCCESS FACTORS

\begin{tabular}{|c|c|c|}
\hline Aspects & ISM Success Factors & Sources \\
\hline \multirow{6}{*}{ People } & \begin{tabular}{ll}
\multicolumn{2}{l}{ Top Management } \\
- $\quad$ knowledge \\
- $\quad$ leadership \\
- $\quad$ commitment \\
\end{tabular} & $\begin{array}{l}{[11],[25],[26],[33],[34],[35]} \\
{[36],[37],[38],[39],[40],[41]} \\
{[42],[43],[44]}\end{array}$ \\
\hline & \begin{tabular}{ll}
\multicolumn{2}{l}{ IS Coordinator Team } \\
$-\quad$ knowledge \\
$-\quad$ commitment \\
- $\quad$ communication skill \\
\end{tabular} & {$[15],[26]$} \\
\hline & $\begin{array}{l}\text { ISM Team } \\
-\quad \text { knowledge } \\
-\quad \text { commitment } \\
-\quad \text { technical skills } \\
-\quad \text { willingness } \\
-\quad \text { cooperation } \\
\end{array}$ & $\begin{array}{l}{[26],[33],[36],[40],[42],[43],[} \\
45]\end{array}$ \\
\hline & 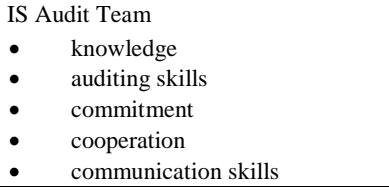 & {$[26],[37],[38],[42],[43]$} \\
\hline & $\begin{array}{l}\text { Employees } \\
\text { - } \quad \text { awareness } \\
\text { - } \quad \text { compliance } \\
\text { - } \quad \text { motivation } \\
\end{array}$ & $\begin{array}{l}{[5],[26],[35],[36],[37],[38]} \\
{[39],[45]}\end{array}$ \\
\hline & $\begin{array}{l}\text { Third Parties } \\
\text { - } \quad \text { awareness } \\
\text { - } \quad \text { compliance }\end{array}$ & {$[26],[38],[42],[43],[46]$} \\
\hline \multirow{2}{*}{$\begin{array}{l}\text { Organisation } \\
\text { al Document }\end{array}$} & 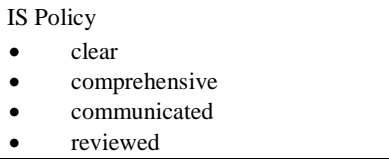 & $\begin{array}{l}{[5],[25],[26],[33],[34],[35],} \\
{[36],[37],[38],[39],[41],[42],} \\
{[43],[45],[47],[48]}\end{array}$ \\
\hline & 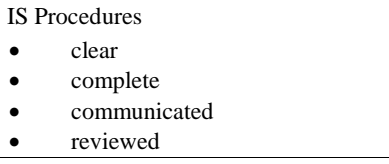 & {$[26],[36],[37],[49]$} \\
\hline \multirow{5}{*}{ Process } & $\begin{array}{l}\text { Resource Planning } \\
\text { - } \quad \text { financial resources } \\
\text { - } \quad \text { human resource }\end{array}$ & $\begin{array}{l}{[26],[33],[34],[35],[38],[42],[} \\
43],[45],[50]\end{array}$ \\
\hline & $\begin{array}{l}\text { Competency Development Awareness } \\
\text { - } \quad \text { awareness programs } \\
\text { - } \quad \text { training programs }\end{array}$ & $\begin{array}{l}{[26],[33],[34],[35],[37],[38],[} \\
39],[42],[43],[45],[48]\end{array}$ \\
\hline & $\begin{array}{l}\text { Risk Management } \\
\text { - } \quad \text { risk assessment } \\
\text { - } \quad \text { risk treatment }\end{array}$ & $\begin{array}{l}{[25],[26],[35],[36],[37],[38],} \\
{[41],[42],[43],[45],[48],[51]}\end{array}$ \\
\hline & $\begin{array}{l}\text { Business Continuity Management } \\
\text { - } \quad \text { plan } \\
\text { - } \quad \text { simulation }\end{array}$ & {$[26],[37],[38],[41],[49],[52]$} \\
\hline & 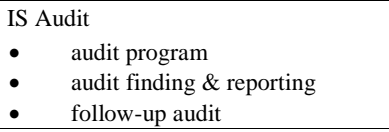 & $\begin{array}{l}{[26],[36],[37],[38],[42],[43],} \\
{[53]}\end{array}$ \\
\hline Technology & $\begin{array}{l}\text { IT } \text { Infrastructure } \\
\bullet \quad \text { software } \\
\bullet \quad \text { hardware }\end{array}$ & $\begin{array}{l}{[5],[26],[36],[38],[42],[43],} \\
{[45],[50],[54],[55]}\end{array}$ \\
\hline
\end{tabular}


On the other hand, a maturity model developed by [57] aims to assess the organisation's ability to meet security objectives. The model defines the process of managing, measuring, and controlling security based on four aspects; governance, security management, system architecture, and service management. Each aspect has its indicators [12]. This model has five levels of compliance which starting from noncompliance to full compliance.

The comparison of the mentioned models is summarised in Table II. Table II shows several ISM success factors are being considered as the maturity dimensions in the existing model. However, the existing models are typically process-oriented which focus more on the process and technology factors and have less emphasis on the people factors. This causes the implementation of ISM is evaluated less comprehensively. People factors play a significant role in ISM [58]; thus, need to be emphasized as well [59]. Therefore, a holistic maturity model is required by incorporating all ISM success factors and their elements to ensure the effectiveness of the ISM implementation.

TABLE II. COMPARISON OF MATURITY MODELS

\begin{tabular}{|c|c|c|c|c|c|c|c|}
\hline \multicolumn{2}{|c|}{$\begin{array}{l}\text { Model/ Basis of } \\
\text { comparisons }\end{array}$} & $\operatorname{COBIT~} 4.1_{[21]}$ & $\begin{array}{l}\text { CMM } \\
\text { [31] }\end{array}$ & $\underset{[32]}{\text { O-ISM3 }}$ & $\begin{array}{c}\text { Cyclical } \\
\text { evaluation } \\
\text { moded } \\
{[56]}\end{array}$ & $\begin{array}{c}\text { IS Assessment } \\
\text { Model } \\
{[46]}\end{array}$ & $\begin{array}{c}\text { IS } \\
\text { Muturity } \\
\text { Model } \\
{[57]}\end{array}$ \\
\hline \multicolumn{2}{|c|}{ The objective of the model } & $\begin{array}{c}\text { Meassure the } \\
\text { current maturity } \\
\text { of an } \\
\text { organisation's } \\
\text { Information } \\
\text { Technology (IT) } \\
\text { processes }\end{array}$ & $\begin{array}{l}\text { Measure the } \\
\text { current } \\
\text { cybersecurity } \\
\text { capacity }\end{array}$ & $\begin{array}{c}\text { Measure ISM } \\
\text { maturity based } \\
\text { on } \\
\text { management } \\
\text { processes in } \\
\text { four aspects; } \\
\text { general, } \\
\text { strutegic, } \\
\text { tactical, and } \\
\text { operational. }\end{array}$ & $\begin{array}{l}\text { As a means to } \\
\text { mensure the } \\
\text { current } \\
\text { situation of IS } \\
\text { management } \\
\text { based on } \\
\text { ISO/IICC } 27002 \\
\text { security } \\
\text { controls. }\end{array}$ & $\begin{array}{c}\text { Assessing } \\
\text { information } \\
\text { security } \\
\text { implementation } \\
\text { levels in } \\
\text { organisations. }\end{array}$ & $\begin{array}{l}\text { Assessing } \\
\text { the ability } \\
\text { of the } \\
\text { organisation } \\
\text { in meeting } \\
\text { security } \\
\text { objectives. }\end{array}$ \\
\hline \multicolumn{2}{|c|}{ Scope of coverage } & 34 processes & 5dimensions & 45 processes & 133 controls & $\begin{array}{l}4 \text { factors / aspects } \\
\text { domains }\end{array}$ & $\begin{array}{l}4 \text { factors / } \\
\text { aspects / } \\
\text { domains }\end{array}$ \\
\hline \multicolumn{2}{|c|}{ Maturity levels } & $\begin{array}{c}\text { Six levels } \\
\text { ranking of 0-5 }\end{array}$ & $\begin{array}{l}\text { Five levels } \\
\text { ranking of } 1 \text { - }\end{array}$ & $\begin{array}{c}\text { Five levels } \\
\text { ranking of } 1-5\end{array}$ & $\begin{array}{l}\text { Six levels } \\
\text { ranking of } 0-5\end{array}$ & $\begin{array}{l}\text { Three levels } \\
\text { ranking of } 1-3\end{array}$ & $\begin{array}{l}\text { Five levels } \\
\text { ranking of } \\
1-5\end{array}$ \\
\hline \multicolumn{8}{|c|}{$\begin{array}{l}\text { ISM success factors involved in } \\
\text { assessment }\end{array}$} \\
\hline \multirow[t]{6}{*}{ People } & Top Management & $\sqrt{ }$ & & & $\sqrt{ }$ & $\sqrt{ }$ & $\checkmark$ \\
\hline & $\begin{array}{l}\text { IS Coordinator } \\
\text { Team }\end{array}$ & & & & & & \\
\hline & ISM Team & $\sqrt{ }$ & $\sqrt{ }$ & & $\sqrt{ }$ & & \\
\hline & IS Audit Team & & & & & & \\
\hline & Employees & $\sqrt{ }$ & & & & $\sqrt{ }$ & \\
\hline & Third Parties & & & & & & $\sqrt{ }$ \\
\hline \multirow{2}{*}{$\begin{array}{l}\text { Organisational } \\
\text { Document }\end{array}$} & IS Policy & $\sqrt{ }$ & $\sqrt{ }$ & $\checkmark$ & $\sqrt{ }$ & $\checkmark$ & \\
\hline & IS Procedures & $\checkmark$ & $\checkmark$ & $\sqrt{ }$ & $\sqrt{ }$ & & \\
\hline \multirow[t]{5}{*}{ Process } & Resource Planning & $\checkmark$ & $\checkmark$ & $\checkmark$ & $\checkmark$ & $\checkmark$ & $\checkmark$ \\
\hline & $\begin{array}{l}\text { Competency } \\
\text { Development \& } \\
\text { Awareness }\end{array}$ & $\sqrt{ }$ & $\checkmark$ & $\sqrt{ }$ & & & $\sqrt{ }$ \\
\hline & Risk Management & $\sqrt{ }$ & $\sqrt{ }$ & $\sqrt{ }$ & & $\sqrt{ }$ & \\
\hline & $\begin{array}{l}\text { Business } \\
\text { Continuity } \\
\text { Management }\end{array}$ & & $\sqrt{7}$ & $\sqrt{ }$ & $\sqrt{ }$ & & \\
\hline & IS Audit & $\sqrt{ }$ & $\sqrt{ }$ & $\sqrt{ }$ & & & $\sqrt{ }$ \\
\hline Technology & IT Infrastructure & $\sqrt{ }$ & $\sqrt{ }$ & $\sqrt{ }$ & & $\checkmark$ & \\
\hline
\end{tabular}




\section{METHODOLOGY}

This study adopts the mixed-method approach, which comprises both qualitative and quantitative data collection and analysis. This approach involves four main phases: theoretical, empirical, model development, and model validation. Fig. 1 illustrates the research design.

\begin{tabular}{|l|l|}
\hline Phase 1 & $\bullet$ Theoritical \\
\hline Phase 2 & $\bullet$ Empirical \\
\hline Phase 3 & $\bullet$ Model Development \\
\hline Phase 4 & $\bullet$ Model Validation \\
\hline
\end{tabular}

Fig. 1. Research Design.

\section{A. Phase 1: Theoretical}

The theoretical study reviewed published and unpublished documents in multiple online databases such as ACM Digital Library, Web of Science, Science Direct, Google Scholar, Proquest, IEEE Explorer, Mendeley and CiteSeer to identify the ISM success factors and ISM maturity models. The selected documents were then analysed qualitatively using content analysis. The preliminary findings of this study have been reported in [44].

\section{B. Phase2: Empirical}

The empirical study is to verify the success factors and identify each success factor's maturity dimension and levels. As it involves various aspects, it is thus divided into three parts:

- Empirical I: The purpose of Empirical I is to verify the ISM success factors derived from the theoretical study and discover other relevant factors from practitioners' views. This study used semi-structured interviews. A series of individual and focus group interviews with experienced ISM practitioners was conducted. The findings of this study have been reported in [26].

- Empirical II: The purpose of Empirical II is to confirm and refine the findings of Empirical I through a largescale survey. A total of 400 questionnaires were sent to respondents in public and private agencies. The data collected from the survey were analysed using Statistical Analysis. The findings of this empirical II have been reported in [60].
- Empirical III: A series of interviews with six experts were conducted to identify the ISM maturity dimensions and levels. The selection of experts was based on their experience, knowledge, and expertise in ISM. Contents analysis technique was used to analyse the data.

\section{Phase 3: Model Development}

The ISM maturity model was developed using the findings from Empirical I, II, and III. The identified success factors, dimensions, and levels were used as the components in the maturity model.

The development of this maturity model is guided by the International Standards ISO / IEC 33004: 2015 Information technology - Process assessment - Requirements for process reference, process assessment and maturity models [61]. In addition, the measurement theory of [62] and [63], which introduced the ordinal scale, was also used as a basis in the development of this ISM maturity model.

\section{Phase 4: Model Validation}

This phase evaluates the accuracy of the proposed model through expert review. A series of interviews with three experts were conducted to evaluate the accuracy and suitability of the proposed model. Based on the review, the proposed model was improved.

\section{RESUlT AND FINDING}

Based on the experts reviewed, the final Organisational ISM Maturity Model has 4 aspects, 14 factors, 42 elements, and 57 maturity dimensions. The 14 factors are grouped under four main aspects namely People, Organisational Document, Process and Technology. Each factor has its own elements. Each element has specific dimensions. Each dimension has five levels of maturity; maturity level 1 to maturity level 5 where Level 1 is the lowest level of maturity while Level 5 is the highest level of maturity. The finalised Organisational ISM maturity model is shown in Table III.

This study has produced a comprehensive model of measuring organisational ISM maturity. In contrast to the existing model, this Organisational ISM Maturity Model contains factors from process and technology aspects and contains factors from non-technical aspects, namely People and Organisational Document. Every identified factor was then sorted according to its categories and subsequently determined its maturity dimensions. Based on the arrangement of categories and factors generated, this study helps the organisations to self-assessing the maturity level of their ISM implementation systematically. Through the assessment conducted, the organisation can identify their ISM maturity level while further improving the implementation of their ISM. 
TABLE III. ORGANISATIONAL INFORMATION SECURITY MANAGEMENT MATURITY MODEL

\begin{tabular}{|c|c|c|c|c|c|c|c|c|}
\hline Aspects & Factors & Elements & $\begin{array}{l}\text { Maturity } \\
\text { Dimensions }\end{array}$ & Level 1 & Level 2 & Level 3 & Level 4 & Level 5 \\
\hline \multirow{11}{*}{ People } & \multirow{3}{*}{$\begin{array}{l}\text { Top } \\
\text { Management }\end{array}$} & Leadership & $\begin{array}{l}\text { Personnel/unit } \\
\text { involvement in } \\
\text { ISM }\end{array}$ & $\begin{array}{l}\text { ISM } \\
\text { implementation } \\
\text { involves only the } \\
\text { ICT unit. }\end{array}$ & $\begin{array}{l}\text { ISM } \\
\text { implementation } \\
\text { involves ICT } \\
\text { unit and process } \\
\text { owners. }\end{array}$ & $\begin{array}{l}\text { ISM } \\
\text { implementation } \\
\text { involves the ICT } \\
\text { unit, process } \\
\text { owners, and } \\
\text { administrative } \\
\text { unit. }\end{array}$ & $\begin{array}{l}\text { ISM } \\
\text { implementation } \\
\text { involves the ICT } \\
\text { unit, process } \\
\text { owner, } \\
\text { administrative } \\
\text { unit, and } \\
\text { responsible } \\
\text { units. }\end{array}$ & $\begin{array}{l}\text { ISM } \\
\text { implementation } \\
\text { involves the ICT } \\
\text { unit, process } \\
\text { owners, } \\
\text { administrative } \\
\text { unit, responsible } \\
\text { units, and } \\
\text { stakeholders. }\end{array}$ \\
\hline & & Knowledge & $\begin{array}{l}\text { The percentage } \\
\text { of understanding } \\
\text { the objectives } \\
\text { and security } \\
\text { issues. }\end{array}$ & $\begin{array}{l}\text { Less than } 25 \% \text { of } \\
\text { objectives and } \\
\text { security issues } \\
\text { are understood. }\end{array}$ & $\begin{array}{l}\text { At least } 25 \% \text { of } \\
\text { the objectives } \\
\text { and security } \\
\text { issues are } \\
\text { understood. }\end{array}$ & $\begin{array}{l}\text { At least } 50 \% \text { of } \\
\text { the objectives } \\
\text { and security } \\
\text { issues are } \\
\text { understood. }\end{array}$ & $\begin{array}{l}\text { At least } 75 \% \text { of } \\
\text { the objectives } \\
\text { and security } \\
\text { issues are } \\
\text { understood. }\end{array}$ & $\begin{array}{l}100 \% \text { security } \\
\text { objectives and } \\
\text { issues are } \\
\text { understood. }\end{array}$ \\
\hline & & Commitment & $\begin{array}{l}\text { The response } \\
\text { rate on the ISM } \\
\text { issue. }\end{array}$ & $\begin{array}{l}\text { The response to } \\
\text { the ISM issues is } \\
\text { very slow. }\end{array}$ & $\begin{array}{l}\text { The response to } \\
\text { the ISM issues is } \\
\text { slow. }\end{array}$ & $\begin{array}{l}\text { The response to } \\
\text { the ISM issues is } \\
\text { fairly fast. }\end{array}$ & $\begin{array}{l}\text { The response to } \\
\text { the ISM issues is } \\
\text { fast. }\end{array}$ & $\begin{array}{l}\text { The response to } \\
\text { the ISM issues is } \\
\text { very fast. }\end{array}$ \\
\hline & \multirow{4}{*}{$\begin{array}{l}\text { IS } \\
\text { Coordinator } \\
\text { Team. }\end{array}$} & Knowledge & $\begin{array}{l}\text { The percentage } \\
\text { of IS } \\
\text { Coordinator } \\
\text { Team members } \\
\text { understand the } \\
\text { needs, } \\
\text { governance, and } \\
\text { processes of } \\
\text { ISM. }\end{array}$ & $\begin{array}{l}\text { Less than } 25 \% \text { of } \\
\text { IS Coordinator } \\
\text { Team members } \\
\text { understand the } \\
\text { needs, } \\
\text { governance, and } \\
\text { processes of } \\
\text { ISM. }\end{array}$ & $\begin{array}{l}\text { At least } 25 \% \text { of } \\
\text { the IS } \\
\text { Coordinator } \\
\text { Team members } \\
\text { understand the } \\
\text { needs, } \\
\text { governance, and } \\
\text { processes of } \\
\text { ISM. }\end{array}$ & $\begin{array}{l}\text { At least } 50 \% \text { of } \\
\text { the IS } \\
\text { Coordinator } \\
\text { Team members } \\
\text { understand the } \\
\text { needs, } \\
\text { governance, and } \\
\text { processes of } \\
\text { ISM. }\end{array}$ & $\begin{array}{l}\text { At least } 75 \% \text { of } \\
\text { the IS } \\
\text { Coordinator } \\
\text { Team members } \\
\text { understand the } \\
\text { needs, } \\
\text { governance, and } \\
\text { processes of } \\
\text { ISM. }\end{array}$ & $\begin{array}{l}100 \% \text { of the IS } \\
\text { Coordinator } \\
\text { Team members } \\
\text { understand the } \\
\text { needs, } \\
\text { governance, and } \\
\text { processes of } \\
\text { ISM. }\end{array}$ \\
\hline & & Commitment & $\begin{array}{l}\text { The percentage } \\
\text { of the ISM } \\
\text { planning } \\
\text { schedule is } \\
\text { achieved. }\end{array}$ & $\begin{array}{l}\text { Less than } 25 \% \text { of } \\
\text { the ISM } \\
\text { planning } \\
\text { schedule is } \\
\text { achieved. }\end{array}$ & $\begin{array}{l}\text { At least } 25 \% \text { of } \\
\text { the ISM } \\
\text { planning } \\
\text { schedule is } \\
\text { achieved }\end{array}$ & $\begin{array}{l}\text { At least } 50 \% \text { of } \\
\text { the ISM } \\
\text { planning } \\
\text { schedule is } \\
\text { achieved. }\end{array}$ & $\begin{array}{l}\text { At least } 75 \% \text { of } \\
\text { the ISM } \\
\text { planning } \\
\text { schedule is } \\
\text { achieved. }\end{array}$ & $\begin{array}{l}100 \% \text { of the ISM } \\
\text { planning } \\
\text { schedule is } \\
\text { achieved. }\end{array}$ \\
\hline & & \multirow[b]{2}{*}{$\begin{array}{l}\text { Communicatio } \\
\text { n Skills }\end{array}$} & $\begin{array}{l}\text { The clarity of the } \\
\text { information } \\
\text { presented. }\end{array}$ & Very unclear. & Unclear. & Quite clear. & Clear. & Very clear. \\
\hline & & & $\begin{array}{l}\text { The attitude of } \\
\text { IS Coordinator } \\
\text { Team members } \\
\text { when } \\
\text { communicating }\end{array}$ & $\begin{array}{l}\text { Being not open } \\
\text { and not } \\
\text { persuasive. }\end{array}$ & $\begin{array}{l}\text { Being less open } \\
\text { and less } \\
\text { persuasive. }\end{array}$ & $\begin{array}{l}\text { Being a little } \\
\text { open and a little } \\
\text { persuasive. }\end{array}$ & $\begin{array}{l}\text { Being open and } \\
\text { persuasive. }\end{array}$ & $\begin{array}{l}\text { Being very open } \\
\text { and very } \\
\text { persuasive. }\end{array}$ \\
\hline & \multirow{3}{*}{ ISM Team } & Knowledge & $\begin{array}{l}\text { The percentage } \\
\text { of ISM team } \\
\text { members are } \\
\text { knowledgeable } \\
\text { in IS domain. }\end{array}$ & $\begin{array}{l}\text { Less than } 25 \% \text { of } \\
\text { ISM team } \\
\text { members are } \\
\text { knowledgeable } \\
\text { in IS domain. }\end{array}$ & $\begin{array}{l}\text { At least } 25 \% \text { of } \\
\text { ISM team } \\
\text { members are } \\
\text { knowledgeable } \\
\text { in IS domain. }\end{array}$ & $\begin{array}{l}\text { At least } 50 \% \text { of } \\
\text { ISM team } \\
\text { members are } \\
\text { knowledgeable } \\
\text { in IS domain. }\end{array}$ & $\begin{array}{l}\text { At least } 75 \% \text { of } \\
\text { ISM team } \\
\text { members are } \\
\text { knowledgeable } \\
\text { in IS domain. }\end{array}$ & $\begin{array}{l}100 \% \text { of ISM } \\
\text { team members } \\
\text { are } \\
\text { knowledgeable } \\
\text { in IS domain. }\end{array}$ \\
\hline & & \multirow{2}{*}{$\begin{array}{l}\text { Technical } \\
\text { Skills }\end{array}$} & $\begin{array}{l}\text { The average } \\
\text { duration of ISM } \\
\text { team members' } \\
\text { involvement in } \\
\text { implementing IS } \\
\text { operations. }\end{array}$ & Less than 1 year. & $\begin{array}{l}\text { Between } 1 \text { - } 2 \\
\text { years. }\end{array}$ & $\begin{array}{l}\text { Between } 2 \text { - } 3 \\
\text { years. }\end{array}$ & $\begin{array}{l}\text { Between } 3 \text { - } 4 \\
\text { years. }\end{array}$ & Over 4 years. \\
\hline & & & $\begin{array}{l}\text { The capability of } \\
\text { ISM team } \\
\text { members to } \\
\text { complete IS } \\
\text { operations. }\end{array}$ & $\begin{array}{l}\text { Unable to } \\
\text { complete IS } \\
\text { operations at a } \\
\text { specific time } \\
\text { without support } \\
\text { from consultants. }\end{array}$ & $\begin{array}{l}\text { Slightly capable } \\
\text { to complete IS } \\
\text { operations at } \\
\text { specific times } \\
\text { without support } \\
\text { from consultants. }\end{array}$ & $\begin{array}{l}\text { Moderately } \\
\text { capable to } \\
\text { complete IS } \\
\text { operations at } \\
\text { specific times } \\
\text { without support } \\
\text { from consultants. }\end{array}$ & $\begin{array}{l}\text { Capable to } \\
\text { complete IS } \\
\text { operations at } \\
\text { specific times } \\
\text { without support } \\
\text { from consultants. }\end{array}$ & $\begin{array}{l}\text { Very capable to } \\
\text { complete IS } \\
\text { operations at } \\
\text { specific times } \\
\text { without support } \\
\text { from consultants. }\end{array}$ \\
\hline & & Commitment & $\begin{array}{l}\text { The percentage } \\
\text { of ISM team } \\
\text { members } \\
\text { committed to } \\
\text { implementing IS } \\
\text { operations. }\end{array}$ & $\begin{array}{l}\text { Less than } 25 \% \text { of } \\
\text { ISM team } \\
\text { members } \\
\text { committed to } \\
\text { implementing IS } \\
\text { operations. }\end{array}$ & $\begin{array}{l}\text { At least } 25 \% \text { of } \\
\text { ISM team } \\
\text { members } \\
\text { committed to } \\
\text { implementing IS } \\
\text { operations. }\end{array}$ & $\begin{array}{l}\text { At least } 50 \% \text { of } \\
\text { ISM team } \\
\text { members } \\
\text { committed to } \\
\text { implementing IS } \\
\text { operations. }\end{array}$ & $\begin{array}{l}\text { At least } 75 \% \text { of } \\
\text { ISM team } \\
\text { members } \\
\text { committed to } \\
\text { implementing IS } \\
\text { operations. }\end{array}$ & $\begin{array}{l}100 \% \text { of ISM } \\
\text { team members } \\
\text { committed to } \\
\text { implementing IS } \\
\text { operations. }\end{array}$ \\
\hline
\end{tabular}




\begin{tabular}{|c|c|c|c|c|c|c|c|}
\hline & & $\begin{array}{l}\text { The percentage } \\
\text { of ISM team } \\
\text { members follow } \\
\text { security } \\
\text { procedures. }\end{array}$ & $\begin{array}{l}\text { Less than } 25 \% \text { of } \\
\text { ISM team } \\
\text { members follow } \\
\text { the security } \\
\text { procedures. }\end{array}$ & $\begin{array}{l}\text { At least } 25 \% \text { of } \\
\text { ISM team } \\
\text { members follow } \\
\text { the security } \\
\text { procedures. }\end{array}$ & $\begin{array}{l}\text { At least } 50 \% \text { of } \\
\text { ISM team } \\
\text { members follow } \\
\text { the security } \\
\text { procedures. }\end{array}$ & $\begin{array}{l}\text { At least } 75 \% \text { of } \\
\text { ISM team } \\
\text { members follow } \\
\text { the security } \\
\text { procedures. }\end{array}$ & $\begin{array}{l}100 \% \text { of ISM } \\
\text { team members } \\
\text { follow the } \\
\text { security } \\
\text { procedures. }\end{array}$ \\
\hline & Willingness & $\begin{array}{l}\text { The percentage } \\
\text { of ISM team } \\
\text { members willing } \\
\text { to accept and } \\
\text { implement } \\
\text { changes. }\end{array}$ & $\begin{array}{l}\text { Less than } 25 \% \text { of } \\
\text { ISM team } \\
\text { members willing } \\
\text { to accept and } \\
\text { implement } \\
\text { changes. }\end{array}$ & $\begin{array}{l}\text { At least } 25 \% \text { of } \\
\text { ISM team } \\
\text { members willing } \\
\text { to accept and } \\
\text { implement } \\
\text { changes. }\end{array}$ & $\begin{array}{l}\text { At least } 50 \% \text { of } \\
\text { ISM team } \\
\text { members willing } \\
\text { to accept and } \\
\text { implement } \\
\text { changes. }\end{array}$ & $\begin{array}{l}\text { At least } 75 \% \text { of } \\
\text { ISM team } \\
\text { members willing } \\
\text { to accept and } \\
\text { implement } \\
\text { changes. }\end{array}$ & $\begin{array}{l}100 \% \text { of ISM } \\
\text { team members } \\
\text { willing to accept } \\
\text { and implement } \\
\text { changes. }\end{array}$ \\
\hline & Cooperation & $\begin{array}{l}\text { Level of } \\
\text { understanding } \\
\text { between ISM } \\
\text { team members to } \\
\text { achieve IS } \\
\text { objectives. }\end{array}$ & $\begin{array}{l}\text { There is no } \\
\text { understanding to } \\
\text { achieve IS } \\
\text { objectives. }\end{array}$ & $\begin{array}{l}\text { Lack of } \\
\text { understanding to } \\
\text { achieve IS } \\
\text { objectives. }\end{array}$ & $\begin{array}{l}\text { Quite } \\
\text { understanding to } \\
\text { achieve IS } \\
\text { objectives. }\end{array}$ & $\begin{array}{l}\text { Understanding to } \\
\text { achieve IS } \\
\text { objectives. }\end{array}$ & $\begin{array}{l}\text { Very } \\
\text { understanding to } \\
\text { achieve IS } \\
\text { objectives. }\end{array}$ \\
\hline \multirow{6}{*}{$\begin{array}{l}\text { IS Audit } \\
\text { Team }\end{array}$} & & $\begin{array}{l}\text { The percentage } \\
\text { of IS audit team } \\
\text { members are } \\
\text { knowledgeable } \\
\text { in IS standards. }\end{array}$ & $\begin{array}{l}\text { Less than } 25 \% \text { of } \\
\text { IS audit team } \\
\text { members are } \\
\text { knowledgeable } \\
\text { in IS standards. }\end{array}$ & $\begin{array}{l}\text { At least } 25 \% \text { of } \\
\text { IS audit team } \\
\text { members are } \\
\text { knowledgeable } \\
\text { in IS standards. }\end{array}$ & $\begin{array}{l}\text { At least } 50 \% \text { of } \\
\text { IS audit team } \\
\text { members are } \\
\text { knowledgeable } \\
\text { in IS standards. }\end{array}$ & $\begin{array}{l}\text { At least } 75 \% \text { of } \\
\text { IS audit team } \\
\text { members are } \\
\text { knowledgeable } \\
\text { in IS standards. }\end{array}$ & $\begin{array}{l}100 \% \text { of IS audit } \\
\text { team members } \\
\text { are } \\
\text { knowledgeable } \\
\text { in IS standards. }\end{array}$ \\
\hline & Knowledge & $\begin{array}{l}\text { The percentage } \\
\text { of IS audit team } \\
\text { members are } \\
\text { knowledgeable } \\
\text { in the ISM scope } \\
\text { of the audited } \\
\text { organisation. }\end{array}$ & $\begin{array}{l}\text { Less than } 25 \% \text { of } \\
\text { IS audit team } \\
\text { members are } \\
\text { knowledgeable } \\
\text { in the ISM scope } \\
\text { of the audited } \\
\text { organisation. }\end{array}$ & $\begin{array}{l}\text { At least } 25 \% \text { of } \\
\text { IS audit team } \\
\text { members are } \\
\text { knowledgeable } \\
\text { in the ISM scope } \\
\text { of the audited } \\
\text { organisation. }\end{array}$ & $\begin{array}{l}\text { At least } 50 \% \text { of } \\
\text { IS audit team } \\
\text { members are } \\
\text { knowledgeable } \\
\text { in the ISM scope } \\
\text { of the audited } \\
\text { organisation. }\end{array}$ & $\begin{array}{l}\text { At least } 75 \% \text { of } \\
\text { IS audit team } \\
\text { members are } \\
\text { knowledgeable } \\
\text { in the ISM scope } \\
\text { of the audited } \\
\text { organisation. }\end{array}$ & $\begin{array}{l}100 \% \text { of IS audit } \\
\text { team members } \\
\text { are } \\
\text { knowledgeable } \\
\text { in the ISM scope } \\
\text { of the audited } \\
\text { organisation. }\end{array}$ \\
\hline & Auditing skills & $\begin{array}{l}\text { The frequency of } \\
\text { audit team } \\
\text { members' } \\
\text { involvement in } \\
\text { internal and } \\
\text { external audit } \\
\text { within } 3 \text { years. }\end{array}$ & $\begin{array}{l}1 \text { time involved } \\
\text { in } \\
\text { internal/external } \\
\text { audit. }\end{array}$ & $\begin{array}{l}2 \text { times involved } \\
\text { in } \\
\text { internal/external } \\
\text { audit. }\end{array}$ & $\begin{array}{l}3 \text { times involved } \\
\text { in } \\
\text { internal/external } \\
\text { audit. }\end{array}$ & $\begin{array}{l}4 \text { times involved } \\
\text { in } \\
\text { internal/external } \\
\text { audit. }\end{array}$ & $\begin{array}{l}\text { More than } 4 \\
\text { times involved in } \\
\text { internal/external } \\
\text { audit. }\end{array}$ \\
\hline & Commitment & $\begin{array}{l}\text { Level of detail in } \\
\text { writing audit } \\
\text { notes. }\end{array}$ & Not detailed. & Lack of detail. & Quite Detailed & Detailed. & Very detailed. \\
\hline & Cooperation & $\begin{array}{l}\text { The work culture } \\
\text { of IS audit team } \\
\text { members during } \\
\text { audit findings } \\
\text { discussion. }\end{array}$ & $\begin{array}{l}\text { No cooperation } \\
\text { during audit } \\
\text { findings } \\
\text { discussion. }\end{array}$ & $\begin{array}{l}\text { Lack of co- } \\
\text { operation during } \\
\text { audit findings } \\
\text { discussion. }\end{array}$ & $\begin{array}{l}\text { Quite cooperate } \\
\text { during audit } \\
\text { findings } \\
\text { discussion. }\end{array}$ & $\begin{array}{l}\text { Cooperate during } \\
\text { audit findings } \\
\text { discussion. }\end{array}$ & $\begin{array}{l}\text { Strongly } \\
\text { cooperate during } \\
\text { audit findings } \\
\text { discussion. }\end{array}$ \\
\hline & $\begin{array}{l}\text { Communicatio } \\
\text { n Skills }\end{array}$ & $\begin{array}{l}\text { The clarity of } \\
\text { information } \\
\text { delivery (oral } \\
\text { and written). }\end{array}$ & Very unclear. & Unclear. & Quite clear. & Clear. & Very clear. \\
\hline \multirow{3}{*}{ Employee } & Awareness & $\begin{array}{l}\text { The percentage } \\
\text { of employees' } \\
\text { awareness } \\
\text { toward IS policy. }\end{array}$ & $\begin{array}{l}\text { Less than } 25 \% \text { of } \\
\text { employees are } \\
\text { aware of IS } \\
\text { policy. }\end{array}$ & $\begin{array}{l}\text { At least } 25 \% \text { of } \\
\text { employees are } \\
\text { aware of IS } \\
\text { policy. }\end{array}$ & $\begin{array}{l}\text { At least } 50 \% \text { of } \\
\text { employees are } \\
\text { aware of IS } \\
\text { policy. }\end{array}$ & $\begin{array}{l}\text { At least } 75 \% \text { of } \\
\text { employees are } \\
\text { aware of IS } \\
\text { policy. }\end{array}$ & $\begin{array}{l}100 \% \text { of } \\
\text { employees aware } \\
\text { of IS policy. }\end{array}$ \\
\hline & Compliance & $\begin{array}{l}\text { The percentage } \\
\text { of employees' } \\
\text { compliance with } \\
\text { IS policy. }\end{array}$ & $\begin{array}{l}\text { Less than } 25 \% \text { of } \\
\text { employees } \\
\text { comply with IS } \\
\text { policy. }\end{array}$ & $\begin{array}{l}\text { At least } 25 \% \text { of } \\
\text { employees } \\
\text { comply with IS } \\
\text { policy. }\end{array}$ & $\begin{array}{l}\text { At least } 50 \% \text { of } \\
\text { employees } \\
\text { comply with IS } \\
\text { policy. }\end{array}$ & $\begin{array}{l}\text { At least } 75 \% \text { of } \\
\text { employees } \\
\text { comply with IS } \\
\text { policy. }\end{array}$ & $\begin{array}{l}100 \% \text { of } \\
\text { employees } \\
\text { comply with IS } \\
\text { policy. }\end{array}$ \\
\hline & Motivation & $\begin{array}{l}\text { The frequency of } \\
\text { employees } \\
\text { receiving } \\
\text { appreciation. }\end{array}$ & $\begin{array}{l}\text { Never received } \\
\text { an appreciation. }\end{array}$ & $\begin{array}{l}\text { Rarely receive } \\
\text { an appreciation. }\end{array}$ & $\begin{array}{l}\text { Quite often } \\
\text { receive } \\
\text { appreciation. }\end{array}$ & $\begin{array}{l}\text { Often receive } \\
\text { appreciation. }\end{array}$ & $\begin{array}{l}\text { Very often } \\
\text { receive } \\
\text { appreciation. }\end{array}$ \\
\hline \multirow[b]{2}{*}{ Third parties } & Awareness & $\begin{array}{l}\text { The percentage } \\
\text { of third parties' } \\
\text { awareness } \\
\text { toward IS policy. }\end{array}$ & $\begin{array}{l}\text { Less than } 25 \% \text { of } \\
\text { third parties are } \\
\text { aware of IS } \\
\text { policy. }\end{array}$ & $\begin{array}{l}\text { At least } 25 \% \text { of } \\
\text { third parties are } \\
\text { aware of IS } \\
\text { policy. }\end{array}$ & $\begin{array}{l}\text { At least } 50 \% \text { of } \\
\text { third parties are } \\
\text { aware of IS } \\
\text { policy. }\end{array}$ & $\begin{array}{l}\text { At least } 75 \% \text { of } \\
\text { third parties are } \\
\text { aware of IS } \\
\text { policy. }\end{array}$ & $\begin{array}{l}100 \% \text { of third } \\
\text { parties are aware } \\
\text { of IS policy. }\end{array}$ \\
\hline & Compliance & $\begin{array}{l}\text { The percentage } \\
\text { of third parties' } \\
\text { compliance with } \\
\text { IS policy and } \\
\text { contracts. }\end{array}$ & $\begin{array}{l}\text { Less than } 25 \% \text { of } \\
\text { third parties } \\
\text { comply with IS } \\
\text { policy and } \\
\text { contracts. }\end{array}$ & $\begin{array}{l}\text { At least } 25 \% \text { of } \\
\text { third parties } \\
\text { comply with IS } \\
\text { policy and } \\
\text { contracts. }\end{array}$ & $\begin{array}{l}\text { At least } 50 \% \text { of } \\
\text { third parties } \\
\text { comply with IS } \\
\text { policy contracts. }\end{array}$ & $\begin{array}{l}\text { At least } 75 \% \text { of } \\
\text { third parties } \\
\text { comply with IS } \\
\text { policy contracts. }\end{array}$ & $\begin{array}{l}100 \% \text { of third } \\
\text { parties comply } \\
\text { with IS policy } \\
\text { and contracts. }\end{array}$ \\
\hline
\end{tabular}




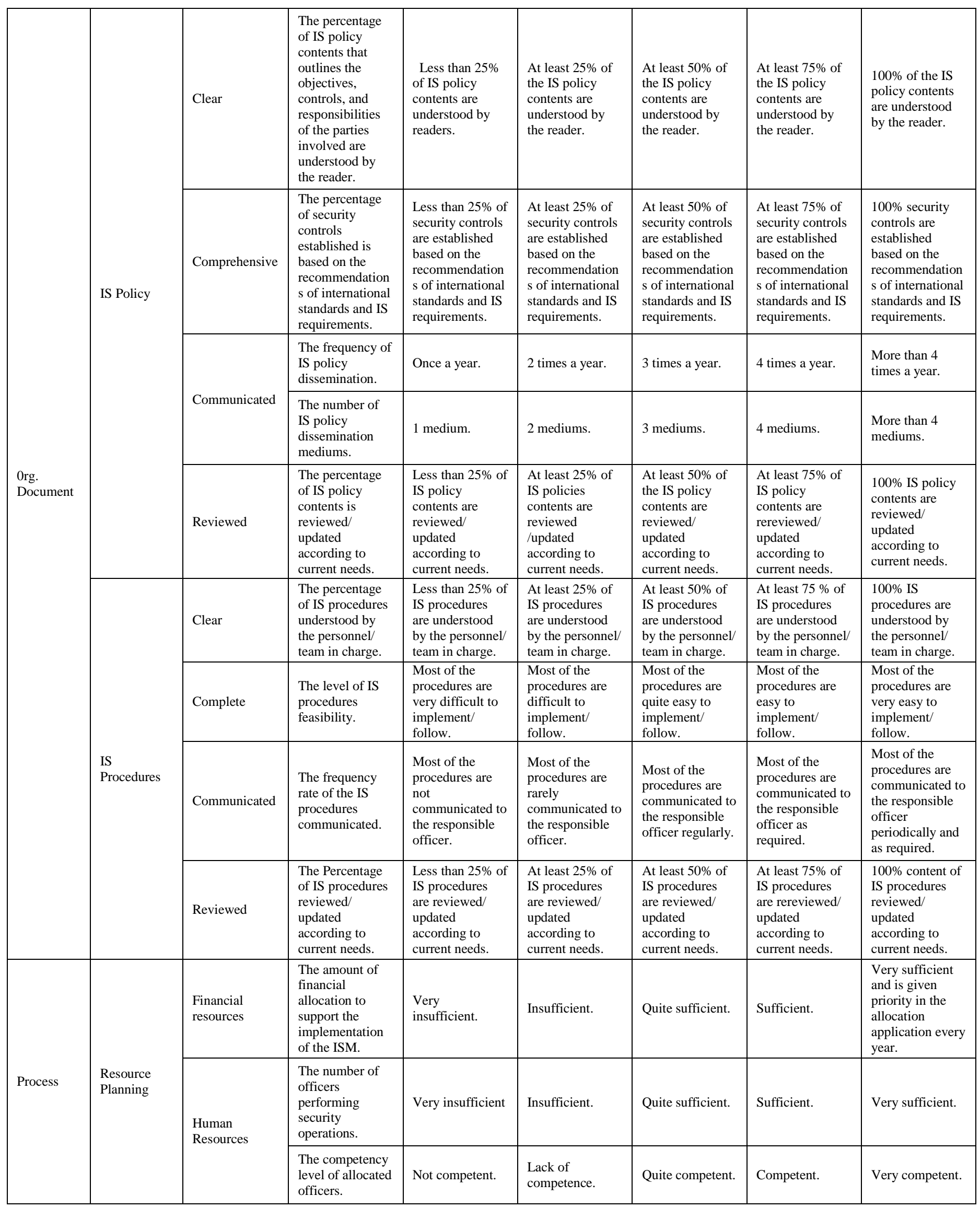




\begin{tabular}{|c|c|c|c|c|c|c|c|}
\hline \multirow{5}{*}{$\begin{array}{l}\text { Competency } \\
\text { Developmen } \\
\text { t \& } \\
\text { Awareness }\end{array}$} & \multirow{2}{*}{$\begin{array}{l}\text { Training } \\
\text { Programmes }\end{array}$} & $\begin{array}{l}\text { The suitability of } \\
\text { the training } \\
\text { programmes } \\
\text { given to } \\
\text { employees and } \\
\text { team members. }\end{array}$ & $\begin{array}{l}\text { Most of the } \\
\text { training } \\
\text { programs given } \\
\text { to staff and team } \\
\text { members do not } \\
\text { suit the work } \\
\text { scope. }\end{array}$ & $\begin{array}{l}\text { Most of the } \\
\text { training } \\
\text { programs given } \\
\text { to staff and team } \\
\text { members are less } \\
\text { suited to the } \\
\text { work scope. }\end{array}$ & $\begin{array}{l}\text { Most of the } \\
\text { training } \\
\text { programs given } \\
\text { to staff and team } \\
\text { members are } \\
\text { quite suited to } \\
\text { the work scope. }\end{array}$ & $\begin{array}{l}\text { Most of the } \\
\text { training } \\
\text { programs given } \\
\text { to staff and team } \\
\text { members are } \\
\text { suited to the } \\
\text { work scope. }\end{array}$ & $\begin{array}{l}\text { Most of the } \\
\text { training } \\
\text { programs given } \\
\text { to staff and team } \\
\text { members are } \\
\text { well suited to the } \\
\text { work scope. }\end{array}$ \\
\hline & & $\begin{array}{l}\text { The knowledge } \\
\text { of the employees } \\
\text { and team } \\
\text { members after } \\
\text { attending } \\
\text { training } \\
\text { programs. }\end{array}$ & Very low. & Low. & Moderate. & Good. & Excellent. \\
\hline & \multirow{3}{*}{$\begin{array}{l}\text { Awareness } \\
\text { Programmes }\end{array}$} & $\begin{array}{l}\text { The number of } \\
\text { awareness } \\
\text { programs } \\
\text { mediums in a } \\
\text { year. }\end{array}$ & $\begin{array}{l}\text { Awareness } \\
\text { programs are } \\
\text { implemented } \\
\text { through } 1 \\
\text { medium. }\end{array}$ & $\begin{array}{l}\text { Awareness } \\
\text { programs are } \\
\text { implemented } \\
\text { through } 2 \\
\text { mediums. }\end{array}$ & $\begin{array}{l}\text { Awareness } \\
\text { programs are } \\
\text { implemented } \\
\text { through } 3 \\
\text { mediums. }\end{array}$ & $\begin{array}{l}\text { Awareness } \\
\text { programs are } \\
\text { implemented } \\
\text { through } 4 \\
\text { mediums. }\end{array}$ & $\begin{array}{l}\text { Awareness } \\
\text { programs are } \\
\text { implemented in } \\
\text { more than } 4 \\
\text { mediums. }\end{array}$ \\
\hline & & $\begin{array}{l}\text { The frequency of } \\
\text { awareness } \\
\text { programs in a } \\
\text { year. }\end{array}$ & Once a year. & Twice a year. & 3 times a year. & 4 times a year. & $\begin{array}{l}\text { More than } 4 \\
\text { times a year. }\end{array}$ \\
\hline & & $\begin{array}{l}\text { The percentage } \\
\text { of security } \\
\text { incidents has } \\
\text { been reduced. }\end{array}$ & $\begin{array}{l}\text { Less than } 25 \% \text { of } \\
\text { security } \\
\text { incidents have } \\
\text { been reduced. }\end{array}$ & $\begin{array}{l}\text { At least } 25 \% \text { of } \\
\text { security } \\
\text { incidents have } \\
\text { been reduced. }\end{array}$ & $\begin{array}{l}\text { At least } 50 \% \text { of } \\
\text { security } \\
\text { incidents have } \\
\text { been reduced. }\end{array}$ & $\begin{array}{l}\text { At least } 75 \% \text { of } \\
\text { security } \\
\text { incidents have } \\
\text { been reduced. }\end{array}$ & $\begin{array}{l}100 \% \text { security } \\
\text { incidents have } \\
\text { been reduced. }\end{array}$ \\
\hline \multirow{4}{*}{$\begin{array}{l}\text { Risk } \\
\text { management }\end{array}$} & \multirow[t]{2}{*}{$\begin{array}{l}\text { Risk } \\
\text { Assessment }\end{array}$} & $\begin{array}{l}\text { The percentage } \\
\text { of process } \\
\text { owners, asset } \\
\text { owners and IS } \\
\text { team's } \\
\text { involvement in } \\
\text { risk assessment. }\end{array}$ & Less than $25 \%$. & At least $25 \%$. & At least $50 \%$. & At least $75 \%$. & $100 \%$ \\
\hline & & $\begin{array}{l}\text { The percentage } \\
\text { of assets } \\
\text { (included in the } \\
\text { scope) that have } \\
\text { been assessed. }\end{array}$ & $\begin{array}{l}\text { Less than } 25 \% \text { of } \\
\text { assets have been } \\
\text { assessed. }\end{array}$ & $\begin{array}{l}\text { At least } 25 \% \text { of } \\
\text { the assets have } \\
\text { been assessed. }\end{array}$ & $\begin{array}{l}\text { At least } 50 \% \text { of } \\
\text { the assets have } \\
\text { been assessed. }\end{array}$ & $\begin{array}{l}\text { At least } 75 \% \text { of } \\
\text { the assets have } \\
\text { been assessed. }\end{array}$ & $\begin{array}{l}100 \% \text { of the } \\
\text { assets have been } \\
\text { assessed. }\end{array}$ \\
\hline & \multirow{2}{*}{ Risk Treatment } & $\begin{array}{l}\text { Level of } \\
\text { treatment } \\
\text { suitability in } \\
\text { managing risk. }\end{array}$ & Not appropriate & Less appropriate & $\begin{array}{l}\text { Quite } \\
\text { appropriate. }\end{array}$ & Appropriate. & $\begin{array}{l}\text { Very } \\
\text { appropriate. }\end{array}$ \\
\hline & & $\begin{array}{l}\text { Percentage of } \\
\text { high-risk assets } \\
\text { that have been } \\
\text { depreciated. }\end{array}$ & Less than $25 \%$. & At least $25 \%$. & At least $50 \%$. & At least $75 \%$. & $100 \%$ \\
\hline \multirow{3}{*}{$\begin{array}{l}\text { Business } \\
\text { continuity } \\
\text { and incident } \\
\text { management }\end{array}$} & & $\begin{array}{l}\text { The percentage } \\
\text { of plan } \\
\text { availability. }\end{array}$ & Less than $25 \%$. & At least $25 \%$. & At least $50 \%$. & At least $75 \%$. & $100 \%$ \\
\hline & Plan & $\begin{array}{l}\text { The percentage } \\
\text { of incidents and } \\
\text { disasters } \\
\text { successfully } \\
\text { handled } \\
\text { (identified, } \\
\text { reported, } \\
\text { recovered) } \\
\text { within a set time. }\end{array}$ & Less than $25 \%$. & At least $25 \%$. & At least $50 \%$. & At least $75 \%$. & $100 \%$. \\
\hline & Simulation & $\begin{array}{l}\text { Diversity of } \\
\text { simulation } \\
\text { implementation } \\
\text { over } 5 \text { years. }\end{array}$ & $\begin{array}{l}\text { The same } \\
\text { simulation was } \\
\text { implemented } \\
\text { over } 5 \text { years. }\end{array}$ & $\begin{array}{l}\text { At least } 2 \\
\text { different } \\
\text { simulations were } \\
\text { implemented } \\
\text { over } 5 \text { years. }\end{array}$ & $\begin{array}{l}\text { At least } 3 \\
\text { different } \\
\text { simulations were } \\
\text { implemented } \\
\text { over } 5 \text { years. }\end{array}$ & $\begin{array}{l}\text { At least } 4 \\
\text { different } \\
\text { simulations were } \\
\text { implemented } \\
\text { over } 5 \text { years. }\end{array}$ & $\begin{array}{l}\text { More than } 4 \\
\text { different } \\
\text { simulations were } \\
\text { implemented } \\
\text { over } 5 \text { years. }\end{array}$ \\
\hline IS Audit & Audit program & $\begin{array}{l}\text { The level of } \\
\text { audit scope. }\end{array}$ & $\begin{array}{l}\text { The scope of the } \\
\text { audit is not } \\
\text { comprehensive. }\end{array}$ & $\begin{array}{l}\text { The scope of the } \\
\text { audit is less } \\
\text { comprehensive. }\end{array}$ & $\begin{array}{l}\text { The scope of the } \\
\text { audit is quite } \\
\text { comprehensive. }\end{array}$ & $\begin{array}{l}\text { The scope of the } \\
\text { audit is } \\
\text { comprehensive. }\end{array}$ & $\begin{array}{l}\text { The scope of the } \\
\text { audit is } \\
\text { comprehensive } \\
\text { and has value- } \\
\text { added. }\end{array}$ \\
\hline
\end{tabular}




\begin{tabular}{|c|c|c|c|c|c|c|c|c|}
\hline & & $\begin{array}{l}\text { Audit Findings } \\
\text { and Reporting }\end{array}$ & $\begin{array}{l}\text { The clarity } \\
\text { percentage of the } \\
\text { audit findings } \\
\text { and reporting. }\end{array}$ & $\begin{array}{l}\text { Less than } 25 \% \text { of } \\
\text { audit findings } \\
\text { are clearly } \\
\text { reported. }\end{array}$ & $\begin{array}{l}\text { At least } 25 \% \text { of } \\
\text { audit findings } \\
\text { are clearly } \\
\text { reported. }\end{array}$ & $\begin{array}{l}\text { At least } 50 \% \text { of } \\
\text { audit findings } \\
\text { are clearly } \\
\text { reported. }\end{array}$ & $\begin{array}{l}\text { At least } 75 \% \text { of } \\
\text { audit findings } \\
\text { are clearly } \\
\text { reported. }\end{array}$ & $\begin{array}{l}100 \% \text { of audit } \\
\text { findings are } \\
\text { clearly reported. }\end{array}$ \\
\hline & & \multirow{2}{*}{$\begin{array}{l}\text { Follow-up } \\
\text { Audit }\end{array}$} & $\begin{array}{l}\text { The level of } \\
\text { follow-up audit } \\
\text { review. }\end{array}$ & $\begin{array}{l}\text { The revision of } \\
\text { the corrective } \\
\text { and preventive } \\
\text { actions is carried } \\
\text { out incomplete. }\end{array}$ & $\begin{array}{l}\text { The revision of } \\
\text { the corrective } \\
\text { and preventive } \\
\text { actions is carried } \\
\text { out less } \\
\text { completely. }\end{array}$ & $\begin{array}{l}\text { The revision of } \\
\text { corrective and } \\
\text { preventive } \\
\text { actions is carried } \\
\text { out quite } \\
\text { completely. }\end{array}$ & $\begin{array}{l}\text { The revision of } \\
\text { the corrective } \\
\text { and preventive } \\
\text { actions is carried } \\
\text { out completely. }\end{array}$ & $\begin{array}{l}\text { The revision of } \\
\text { the corrective } \\
\text { and preventive } \\
\text { actions is carried } \\
\text { out completely } \\
\text { and thoroughly. }\end{array}$ \\
\hline & & & $\begin{array}{l}\text { The accuracy } \\
\text { percentage of the } \\
\text { implementation } \\
\text { of the preventive } \\
\text { and corrective } \\
\text { actions. }\end{array}$ & $\begin{array}{l}\text { Less than } 25 \% \text { of } \\
\text { corrective and } \\
\text { preventive } \\
\text { actions are } \\
\text { implemented } \\
\text { appropriately. }\end{array}$ & $\begin{array}{l}\text { At least } 25 \% \text { of } \\
\text { corrective and } \\
\text { preventive } \\
\text { actions are } \\
\text { implemented } \\
\text { appropriately. }\end{array}$ & $\begin{array}{l}\text { At least } 50 \% \text { of } \\
\text { corrective and } \\
\text { preventive } \\
\text { actions are } \\
\text { implemented } \\
\text { appropriately. }\end{array}$ & $\begin{array}{l}\text { At least } 75 \% \text { of } \\
\text { corrective and } \\
\text { preventive } \\
\text { actions are } \\
\text { implemented } \\
\text { appropriately. }\end{array}$ & $\begin{array}{l}100 \% \text { of } \\
\text { corrective and } \\
\text { preventive } \\
\text { actions are } \\
\text { implemented } \\
\text { appropriately. }\end{array}$ \\
\hline \multirow{4}{*}{$\begin{array}{l}\text { Technolog } \\
\text { y }\end{array}$} & \multirow{4}{*}{$\begin{array}{l}\text { IT } \\
\text { Infrastructur } \\
\text { e }\end{array}$} & \multirow{2}{*}{ Hardware } & $\begin{array}{l}\text { The percentage } \\
\text { of hardware } \\
\text { maintenance. }\end{array}$ & $\begin{array}{l}\text { Less than } 25 \% \text { of } \\
\text { hardware is } \\
\text { maintained on } \\
\text { schedule. }\end{array}$ & $\begin{array}{l}\text { At least } 25 \% \text { of } \\
\text { the hardware is } \\
\text { maintained on } \\
\text { schedule. }\end{array}$ & $\begin{array}{l}\text { At least } 50 \% \text { of } \\
\text { the hardware is } \\
\text { maintained on } \\
\text { schedule. }\end{array}$ & $\begin{array}{l}\text { At least } 75 \% \text { of } \\
\text { the hardware is } \\
\text { maintained on } \\
\text { schedule. }\end{array}$ & $\begin{array}{l}100 \% \text { hardware } \\
\text { is maintained on } \\
\text { schedule. }\end{array}$ \\
\hline & & & $\begin{array}{l}\text { The percentage } \\
\text { of latest } \\
\text { hardware used. }\end{array}$ & $\begin{array}{l}\text { Less than } 25 \% \text { of } \\
\text { the latest } \\
\text { hardware is used. }\end{array}$ & $\begin{array}{l}\text { At least } 25 \% \text { of } \\
\text { the latest } \\
\text { hardware is used. }\end{array}$ & $\begin{array}{l}\text { At least } 50 \% \text { of } \\
\text { the latest } \\
\text { hardware is used. }\end{array}$ & $\begin{array}{l}\text { At least } 75 \% \text { of } \\
\text { the latest } \\
\text { hardware is used }\end{array}$ & $\begin{array}{l}100 \% \text { up-to-date } \\
\text { hardware is } \\
\text { used. }\end{array}$ \\
\hline & & Software & $\begin{array}{l}\text { The percentage } \\
\text { of software } \\
\text { maintenance } \\
\text { (updated } \\
\text { version/security } \\
\text { features in } \\
\text { software } \\
\text { architecture). }\end{array}$ & $\begin{array}{l}\text { Less than } 25 \% \text { of } \\
\text { software is } \\
\text { maintained on } \\
\text { schedule. }\end{array}$ & $\begin{array}{l}\text { At least } 25 \% \text { of } \\
\text { the software is } \\
\text { maintained on } \\
\text { schedule. }\end{array}$ & $\begin{array}{l}\text { At least } 50 \% \text { of } \\
\text { the software is } \\
\text { maintained on } \\
\text { schedule. }\end{array}$ & $\begin{array}{l}\text { At least } 75 \% \text { of } \\
\text { the software is } \\
\text { maintained on } \\
\text { schedule. }\end{array}$ & $\begin{array}{l}100 \% \text { software is } \\
\text { maintained on } \\
\text { schedule. }\end{array}$ \\
\hline & & & $\begin{array}{l}\text { The percentage } \\
\text { of use of } \\
\text { software security } \\
\text { functions. }\end{array}$ & $\begin{array}{l}\text { Less than } 25 \% \text { of } \\
\text { software security } \\
\text { functions are } \\
\text { used. }\end{array}$ & $\begin{array}{l}\text { At least } 25 \% \text { of } \\
\text { software security } \\
\text { functions are } \\
\text { used. }\end{array}$ & $\begin{array}{l}\text { At least } 50 \% \text { of } \\
\text { software security } \\
\text { functions are } \\
\text { used. }\end{array}$ & $\begin{array}{l}\text { At least } 75 \% \text { of } \\
\text { software security } \\
\text { functions are } \\
\text { used. }\end{array}$ & $\begin{array}{l}100 \% \text { software } \\
\text { security } \\
\text { functions are } \\
\text { used. }\end{array}$ \\
\hline
\end{tabular}

\section{CONCLUSION}

ISM is a strategic approach to address IS risks and breaches as well as to reduce IS incidents that can compromise the confidentiality, integrity and availability of organisational information. These IS risks, incidents and breaches can be minimised if the organisation implements ISM effectively. The effectiveness of ISM can be achieved if organisations assess the maturity of their ISM practices using a holistic maturity model. A holistic maturity model needs to consider the ISM success factors in every aspect to ensure that the assessment is made comprehensively.

This study has successfully developed a holistic maturity model to help organisations in self-assessing the maturity level of their ISM implementation. This initiative encourages organisations to continue improving the implementation of their ISM from time to time. This model can also be used as guidelines and references to academicians and researchers involved in information security maturity.

Finally, here are some suggestions for further research that can be implemented in the future:

- Specialise the model according to the type of organisation.
This study does not specialise in any particular type of organisation, whether public or private organisation. The nature of service is quite different between those two sectors, and it is believed that organisations in both sectors have relatively slightly different information security controls. Accordingly, detailed studies by the type of organisation can be done in the future to produce a more accurate model.

- Automate the maturity model.

Further studies are proposed to automate the Organisational ISM Maturity Model. The automated ISM maturity model not only simplifies the evaluation process but can also be used for record-keeping and report generating. This allows the organisation to monitor the progress of the ISM, compare the maturity level obtained each year, as well as predict the level of maturity that will be obtained in subsequent years more easily.

\section{ACKNOWLEDGMENT}

The authors would like to thank Faculty of Information Science and Technology, Universiti Kebangsaan Malaysia for supporting this research. The authors also thank the practitioners and experts who participated in this study. 


\section{REFERENCES}

[1] Mirtsch, M., Blind, K., Koch, C. and Dudek, G., "Information security management in ICT and non-ICT sector companies: A preventive innovation perspective," Computers \& Security 109, pp. 1-23, 2021.

[2] Chu, A.M. and So, M.K., "Organizational information security management for sustainable information systems: An unethical employee information security behavior perspective," Sustainability vol. 12 no. 8 , pp. $3163-3187,2020$.

[3] Napitupulu, Darmawan. "A conceptual model of e-government adoption in Indonesia." International Journal on Advanced Science, Engineering and Information Technology 7, vol. 4, pp. 1471-1478, 2017.

[4] Kadhum, Ahmed Meri, and Mohamad Khatim Hasan. "Assessing the determinants of cloud computing services for utilizing health information systems: A case study." International Journal on Advanced Science, Engineering and Information Technology vol.7, no. 2, pp. 503510, 2017.

[5] S. Woodhouse, "Critical Success factors for an Information Security Management System," in 5th International Conference on Information Technology and Applications ICITA 2008, 2008, no. Icita, pp. 244-249.

[6] Jere, Joseph N., and Nsikelelo Ngidi, "A technology, organisation and environment framework analysis of information and communication technology adoption by small and medium enterprises in Pietermaritzburg," South African Journal of Information Management, vol. 22 no. 1 , pp. 1-9, 2020.

[7] Witarsyah, Deden, et al. "The critical factors affecting E-Government adoption in Indonesia: A conceptual framework." International Journal on Advanced Science, Engineering and Information Technology, vol. 7, no. 1, pp. 160-167, 2017.

[8] Ključnikov, A., Mura, L. and Sklenár, D, "Information security management in SMEs: factors of success," Entrepreneurship and Sustainability Issues vol. 6 no. 4, pp. 2081-2094, 2019.

[9] Khan, Navid Ali, Sarfraz Nawaz Brohi, and Noor Zaman, "Ten deadly cyber security threats amid COVID-19 pandemic," TechRxiv Powered by IEEE, 2020.

[10] Tu, C.Z., Yuan, Y., Archer, N. and Connelly, C.E., "Strategic value alignment for information security management: A critical success factor analysis," Information \& Computer Security, pp. 1-28. 2018.

[11] Rahayu, H. and Rozilawati, R., "Contributing Factors for Successful Information Security Management Implementation: A Conceptual Model," International Journal of Innovative Technology and Exploring Engineering (IJITEE) vol. 9, no.2, pp. 4491-4499, 2019.

[12] Makupi, D. and Masese, N., "Determining Information Security Maturity Level of an organization based on ISO 27001," International Journal of Computer Science and Engineering vol. 6, no. 7, pp. 5-11, 2019.

[13] Singh, A.N. and Gupta, M.P., "Information security management practices: case studies from India," Global Business Review vol. 20, no. 1, pp. 253-271, 2019.

[14] Rahayu, H. and Razali, R., "Contributing Factors for Successful Information Security Management Implementation: A Preliminary Review." The Interdisciplinary Of Management, Economic And Social Research, pp. 12-22, 2020.

[15] R. Hashim and R. Razali, "Contributing Factors for Successful Information Security Management Implementation: A Preliminary Review," The Interdisciplinary Of Management, Economic And Social Research, vol. 9, no.2, p.12, 2019.

[16] Center for Strategic and International Studies (CSIS), "Significant Cyber Incidents Since 2006." 2021.

[17] National Cyber Security Agency. Cyber Security Incident Statistics. 2020.

[18] Schmid, M. and Pape, S., "A structured comparison of the corporate information security maturity level," IFIP International Conference on ICT Systems Security and Privacy Protection, pp. 223-237, 2019.

[19] M. F. Saleh, "Information Security Maturity Model," Int. J. Comput. Sci. Secur., vol. 5, no. 3, p. 21, 2011.

[20] T. Dirgahayu and D. Ariyadi, "Assessment to C OBIT 4 . 1 Maturity Model Based on Process Attributes and Control Objectives," in 2015
International Conference on Science in Information Technology (ICSITech), 2015, pp. 343-347.

[21] ITGI, The Control Cbjectives for Information and Related Technology (COBIT 4.1). 2007.

[22] V. C. Aceituno, "Ism3 1.0. Information Security Management Maturity Model," 2004.

[23] W. Sung and S. Kang, "An empirical study on the effect of information security activities: focusing on technology, institution, and awareness,' Proceedings of the 18th Annual International Conference on Digital Government Research, pp. 84-93, 2017.

[24] A. S. Lima, J. N. de Souza, E. C. Branco, and M. Ribas, "Towards value-based information security management monitoring," Integr. Netw. Manag. (IM 2013), 2013 IFIP/IEEE Int. Symp., pp. 1260-1267, 2013.

[25] S. Dzazali and A. H. Zolait, "Assessment of information security maturity: An exploration study of Malaysian public service organizations,” J. Syst. Inf. Technol., vol. 14, no. 1, pp. 23-57, 2012.

[26] M. Zammani and R. Razali, "An Empirical Study of Information Security Management Success Factors," Int. J. Adv. Sci. Eng. Inf. Technol., vol. 6, no. 6, pp. 904-913, 2016.

[27] O. Matrane, M. Talea, C. Okar, and A. Talea, "Towards A New Maturity Model for Information System," 2015 Int. J. Comput. Sci. Issues, vol. 3, no. 12, pp. 268-275, 2015.

[28] K. Randeree, A. Mahal, and A. Narwani, "A business continuity management maturity model for the UAE banking sector," Bus. Process Manag. J., vol. 18, no. 3, pp. 472-492, 2012.

[29] J.V. Carvalho, A. Rocha, R. van de Wetering and A. Abreu, "A Maturity model for hospital information systems," Journal of Business Research, 94, pp. 388-399, 2019.

[30] C. S. Leem, B. W. Kim, E. J. Yu, and M. H. Paek, "Information technology maturity stages and enterprise benchmarking: an empirical study," Ind. Manag. Data Syst., vol. 108, no. 3, pp. 1200-1218, 2008.

[31] G. C. S. C. C. GSCSCC, Cybersecurity Capacity Maturity Model for Nations (CMM). Revised Edition, no. CMM. 2016.

[32] TOG, Open Information Security Management Maturity Model. The Open Group, 2011.

[33] N. Ibrahim and N. Ali, "The Role of Organizational Factors to the Effectiveness of ISMS Implementation in Malaysian Public Sector,' Int. J. Eng. Technol., vol. 7, no. 4.35, pp. 544-550, Nov. 2018.

[34] P. K. Sari, N. Nurshabrina, and Candiwan, "Factor Analysis on Information Security Management in Higher Education Institutions," in 4th International Conference on Cyber and IT Service Management, pp. 1-5. IEEE, 2016., 2016, pp. 1-5.

[35] M. a. Alnatheer, "Information Security Culture Critical Success Factors," in 2015 12th International Conference on Information Technology - New Generations, 2015, pp. 731-735.

[36] P. Bowen, J. Hash, and M. Wilson, NIST Special Publication 800-100 Information Security Handbook: A Guide for Managers, no. October. Maryland, USA: National Institute of Standards and Technology (NIST) in furtherance of its statutory responsibilities under the Federal Information Security, 2006.

[37] A. N. Singh, M. P. Gupta, and A. Ojha, "Identifying factors of 'organizational information security management,"' J. Enterp. Inf. Manag., vol. 27, no. 5, p. 8, 2014.

[38] M. Chander, S. K. Jain, and R. Shankar, "Modeling of information security management parameters in Indian organizations using ISM and MICMAC approach," J. Model. Manag., vol. 8, no. 2, pp. 171-189, 2013.

[39] M. Kazemi, H. Khajouei, and H. Nasrabadi, "Evaluation of information security management system success factors: Case study of Municipal organization," African J. Bus. Manag., vol. 6, no. 14, pp. 4982-4989, 2012.

[40] N. Maarop, N. Mustapha, R. Yusoff, R. Ibrahim, and N. M. M. Zainuddin, "Understanding Success Factors of an Information Security Management System Plan Phase Self-Implementation," Int. J. Soc. Behav. Educ. Econ. Bus. Ind. Eng., vol. 9, no. 3, pp. 884-889, 2015.

[41] A. Cartlidge et al., An Introductory Overview of ITIL® 2011. Orwich: TSO (The Stationery Office), 2012. 
[42] COBIT v 5, COBIT for information security. Rolling Meadows, IL: ISACA, 2012.

[43] ISO, "ISO / IEC 27001: Information Technology - Security Techniques -Information Security Management System - Requirements," 2013.

[44] M. Zammani and R. Razali, "Information security management success factors," Adv. Sci. Lett., vol. 22, no. 8, 2016.

[45] MAMPU, CGSO, C. Malaysia, and MIMOS, "Rangka Kerja Keselamatan Siber Sektor Awam,” 2016.

[46] M. A. Mohamad Stambul; and R. Razali, "An assessment model of information security implementation levels," in Proceedings of the 2011 International Conference on Electrical Engineering and Informatics, 2011, pp. 1-6.

[47] A. Azhari, "Ke Arah Implementasi Sistem Polisi Keselamatan ICT Kajian Kes : Pusat Teknologi Maklumat dan Komunikasi," Universiti Teknologi Malaysia, 2008.

[48] Q. Hu, T. Dinev, P. Hart, and D. Cooke, "Managing Employee Compliance with Information Security Policies: The Critical Role of Top Management and Organizational Culture *," Decis. Sci. J., vol. 00, no. 00, pp. 1-45, 2012.

[49] ISO, "ISO / IEC 27002: Information Technology - Security techniques Code of practice for information security controls," 2013.

[50] R. Diesch, M. Pfaff, and H. Krcmar, "A comprehensive model of information security factors for decision-maker," Computers \& Security, 92, p. 101747, 2020.

[51] M. S. Saleh and A. Alfantookh, "A new comprehensive framework for enterprise information security risk management," Appl. Comput. Informatics, vol. 9, no. 2, pp. 107-118, 2011.

[52] N. Aisyah, S. Abdullah, N. L. Noor, E. Nuraihan, and M. Ibrahim, "Contributing Factor To Business Continuity Management ( $\mathrm{Bcm}$ ) Failure - a Case of Malaysia Public Sector," in Proceedings of the 5th International Conference on Computing and Informatics, ICOCI, 2015, no. 077 , pp. $530-538$.

[53] S. Islam, N. Farah, and T. F. Stafford, "Factors associated with security / cybersecurity audit by internal audit function An international study function,” Manag. Audit. J., vol. 33, no. 4, pp. 377-409, 2018.
[54] A. A. Norman and N. M. Yasin, "Information Systems Security Management (ISSM) Success Factor: Retrospection From the Scholars," Proceedings of the 11th European Conference on Information Warfare and Security, no. July 2012. pp. 339-344, 2012.

[55] S. Chowdhury and K. M. Salahuddin, "A Literature Review of Factors Influencing Implementation of Management Information Systems in Organizations," vol. 12, no. 8, pp. 72-79, 2017.

[56] E. A. Rigon, C. M. Westphall, and D. R. Dos Santos, "A cyclical evaluation model of information security maturity," Inf. Manag. Comput. Secur., vol. 22, no. 3, pp. 265-278, 2014.

[57] Saleh, M. F. "Information Security Maturity Model," International Journal of Computer Science and Security (IJCSS), vol. 5, no. 3, p. 21, 2011.

[58] Y. Goksen, E. Cevik, and H. Avunduk, "A Case Analysis on the Focus on the Maturity Models and Information Technologies," in Procedia Economics and Finance, pp. 208-216, 2015.

[59] H. Stewart and J. Jürjens, "Information security management and the human aspect in organizations," Inf. Comput. Secur., vol. 25, no. 5, pp. 494-534, 2017.

[60] M. Zammani, R. Razali, and D. Singh, "Factors contributing to the success of information security management implementation," International Journal of Advanced Computer Science and Applications, vol. 10, no 11, pp. 384-391, 2019.

[61] ISO, "ISO/IEC 33004:2015 - Information technology - Process assessment - Requirements for process reference, process assessment and maturity models," 2015.

[62] Stevens, S.S., "On the theory of scales of measurement", Science, vol. 103, no. 2684, pp. 677-680, 1946.

[63] Sarle, W.S., "Measurement theory: Frequently asked questions," Disseminations of the International Statistical Applications Institute vol. 1, no. 4, pp. 61-66. 1995. 